\title{
First record of Harmothoe aspera (Hansen, 1879) (Polychaeta: Polynoidae) in the Dutch North Sea
}

\author{
Martijn Spierings ${ }^{1 *}$, Inês Maia Dias ${ }^{1}$, Joop W. P. Coolen ${ }^{1,2}$, Babeth van der Weide ${ }^{1}$ and Joël Cuperus ${ }^{3}$
}

\begin{abstract}
Harmothoe aspera has been recorded in surveys off the Strait of Georgia, the Skagerrak, and the Barents, Mediterranean and Japanese sea. The recorded depth ranged from circa $48 \mathrm{~m}$ to circa $1500 \mathrm{~m}$. This is the first report of $\mathrm{H}$. aspera in the Dutch Exclusive Economic Zone (EEZ), and the first report in a depth range between 15 and $20 \mathrm{~m}$.
\end{abstract}

Keywords: Harmothoe, Harmothoe aspera, Polynoidae, North Sea, Gas platform, Distribution

\section{Background}

Polynoidae (scale worms) is a highly diverse family of polychaetes including more than 700 species (Martin and Britayev 1998). Members of this family are easily recognizable by their dorsal elytra. Polynoidae are mainly considered to be free-living carnivorouspolyphagous (Fauchald and Jumars 1979). Their life strategies and known diets are highly diverse, with more than $20 \%$ being symbiotic species. Polynoidae feed on and interact with all kinds of prey including small crustaceans, echinoderms, sponges, gastropods, hydroids and other polychaetes (Fauchald and Jumars 1979).

Harmothoe aspera (Hansen, 1879) is a species of which little is known. Throughout the years, reports of $H$. aspera have been made from the Strait of Georgia, the Skagerrak, and the Barents, Mediterranean and Japanese sea (Table 1). Depths at which $H$. aspera has been found varies in range from circa $50 \mathrm{~m}$ (Swedish Agency for Marine and Water Management), to circa 200-270 m (Holte 2014; Hassel 2014) and even circa. $1500 \mathrm{~m}$ (Nishimura 1966).

The first record of $H$. aspera was made by Hansen (1879) during the Norwegian North-Atlantic Expedition at station 48 (Lat, $64^{\circ} 36^{\prime} \mathrm{N}$. Long $10^{\circ} 22^{\prime} \mathrm{W}$ ) near the coast of Iceland. The recorded depth was $547 \mathrm{~m}$. The

\footnotetext{
* Correspondence: mspierings88@hotmail.com

${ }^{1}$ Wageningen Marine Research, P.O. Box 57, 1780 AB Den Helder, The Netherlands

Full list of author information is available at the end of the article
}

habitat in which $H$. aspera was found was characterized as dark grey porous clay which contained granite, a few quartz pebbles and a few calcareous shells. The bottom temperature was recorded at $-0,3$ degrees Celsius (Schmelk, 1882). This article is the first report of $H$. aspera in the Dutch Exclusive Economic Zone (EEZ) and the first report for $H$. aspera in a depth range between 15 and $20 \mathrm{~m}$.

\section{Methods}

Two specimens of Harmothoe aspera were observed in a mixed macrofauna sample obtained with a surface supplied airlift as described in Coolen et al. (2015) during marine growth sampling for the RECON (Reef effects of structures in the North Sea) project. Marine growth in these samples consisted out of fouling communities on artificial substrates. Samples were taken $11 \mathrm{~km}$ from the coast of the island of Vlieland within the Dutch EEZ of the North Sea from an artificial substrate at petroleum platform L15-A $\left(53.3295^{\circ} \mathrm{N} 4.8301^{\circ} \mathrm{E}\right)$, at a depth of 15 and $20 \mathrm{~m}$ in June 2014 (Fig. 1). Samples where fixed in a borax buffered $6 \%$ formaldehyde sea water solution, which was replaced with a mix of $70 \%$ ethanol and 3\% glycerol before identification. $H$. aspera was identified by classic taxonomy using the following keys: "Identification of scale worms in British and Irish waters" (Barnich 2011) and "Revision of the Mediterranean species of Harmothoe" (Barnich and Fiege 2000). Both specimens are stored in the Rijkswaterstaat benthic reference collection. 
Table 1 A sample of locations, year and depth in meters of previous observations of $H$. aspera

\begin{tabular}{llll}
\hline Location & Year sampled & Depth $(\mathrm{m})$ & Reference \\
\hline Western Mediterranean & 1990 's & Unknown & (Barnich and Fiege 2000) \\
Coast of Iceland & $1876-1878$ & 547 & (Hansen 1879) \\
Strait of Georgia & 1973 & Unknown & (Levings and McDaniel 1974) \\
West and East Greenland & $1895-1896$ & $200-600$ & (Ditlevsen 1917) \\
Iceland & $1895-1896$ & Unknown & (Ditlevsen 1917) \\
Norway & $1895-1896$ & Unknown & (Ditlevsen 1917) \\
Spitsbergen & $1895-1896$ & Unknown & (Ditlevsen 1917) \\
Motovskt Bay and the open Southern Barents Sea & $2006-2008$ & Unknown & (Anisimova et al. 2010) \\
Portuguese and Spanish Exclusive Economic Zone & Unknown & Unknown & (Ramos, 2010) \\
Trondheimfjord & Unknown & Unknown & (Fiege and Barnich 2009) \\
Southern Japan Sea, Oki Bank & Unknown & $200-1500$ & (Nishimura 1966) \\
Skagerrak and Kattegat & Unknown & Unknown & (Nygren and Pleijel 2015) \\
Barents Sea & 2007 & 266 & (Hassel 2014) \\
Barents Sea & 2007 & 241 & (Holte 2014) \\
Barents Sea & 2007 & 209 & (Holte 2014) \\
Barents Sea & 2007 & 264 & (Holte 2014) \\
Barents Sea & 2007 & 265 & (Holte 2014) \\
Barents Sea & 2007 & 240 & (Holte 2014) \\
Sweden N12 & 2001 & 48 & (Swedish Agency for Marine and Water Management 2015) \\
\hline
\end{tabular}

${ }^{a}$ There are several other records of $H$. aspera from North Atlantic waters occurring on a wide range of substrata in 200 to $1000 \mathrm{~m}$ depth (Barnich and Fiege 2009 )

\section{Results}

\section{Systematics}

Order: Phyllodocida Dales, 1962.

Family: Polynoidae Kinberg, 1856.

Genus: Harmothoe Kinberg, 1856.

Species: Harmothoe aspera (Hansen, 1879).

\section{Material examined}

The two specimens of $H$. aspera have the following specifications. Both were incomplete and damaged at their posterior end, had no sexual products and had most of their elytra missing. Specimen one measured $3.5 \mathrm{~mm}$ long with 19 segments. Segment 18-19 were damaged and only 3 elytra remained (reference collection Rijkswaterstaat). Specimen two measured $2.6 \mathrm{~mm}$ long with 15 segments. The left half of segment 14 was missing with 1 elytron left (reference collection Rijkswaterstaat).

\section{Remarks}

The two specimens showed ventrally inserted lateral antennae, a bilobed prostomium with cephalic peaks and a digitform supra-acicular process on the neuropodia. The specimens were identified and confirmed as $H$. aspera by their elytra (Fig. 2). The margin of their elytra had fringing papillae, the microtubercles were pointed (thorn-shaped/triangular) and the macrotubercles near the posterior margin were large and pyramid shaped. All characteristics fit within the normal range of shapes of
$H$. aspera. The key characteristic used to identify $H$. aspera were the large pyramid shaped macrotubercles.

The presence of large pyramid shaped macrotubercles, as described by Barnich and Fiege (2000), is a clear key characteristic. Nonetheless, $H$. aspera can be confused with three other species: Harmothoe globifera, Harmothoe bellani and Harmothoe lagiscoides serrata. $H$. globifera differs by having much longer marginal papillae on the outer lateral margin of their elytra and the macro- and microtubercles are rounded, globose and covered with small nodular papillae. $H$. bellani differs by having thorn-shaped microtubercles and no macrotubercles. H. lagiscoides serratai differs by having slender and thorn-shaped macrotubercles (Barnich and Fiege 2000).

\section{Habitat}

The L15-A platform has a steel jacket foundation which is standing in waters $22 \mathrm{~m}$ deep with a sandy bottom that is locally covered with rock dump to prevent scouring of the seabed. The two $H$. aspera specimens were found in fouling communities growing on steel in vertical orientation. The community at the sampled depths was dominated by Metridium senile and Tubulariidae covered with Jassa herdmani turf. In total, 60 benthic species where present in the 8 samples obtained at these depths, with representatives from Annelida (15 spp), Arthropoda (20 spp), Bryozoa (5 spp), Cnidaria (3 spp), Echinodermata (3 spp), Mollusca (10 spp) and Porifera 


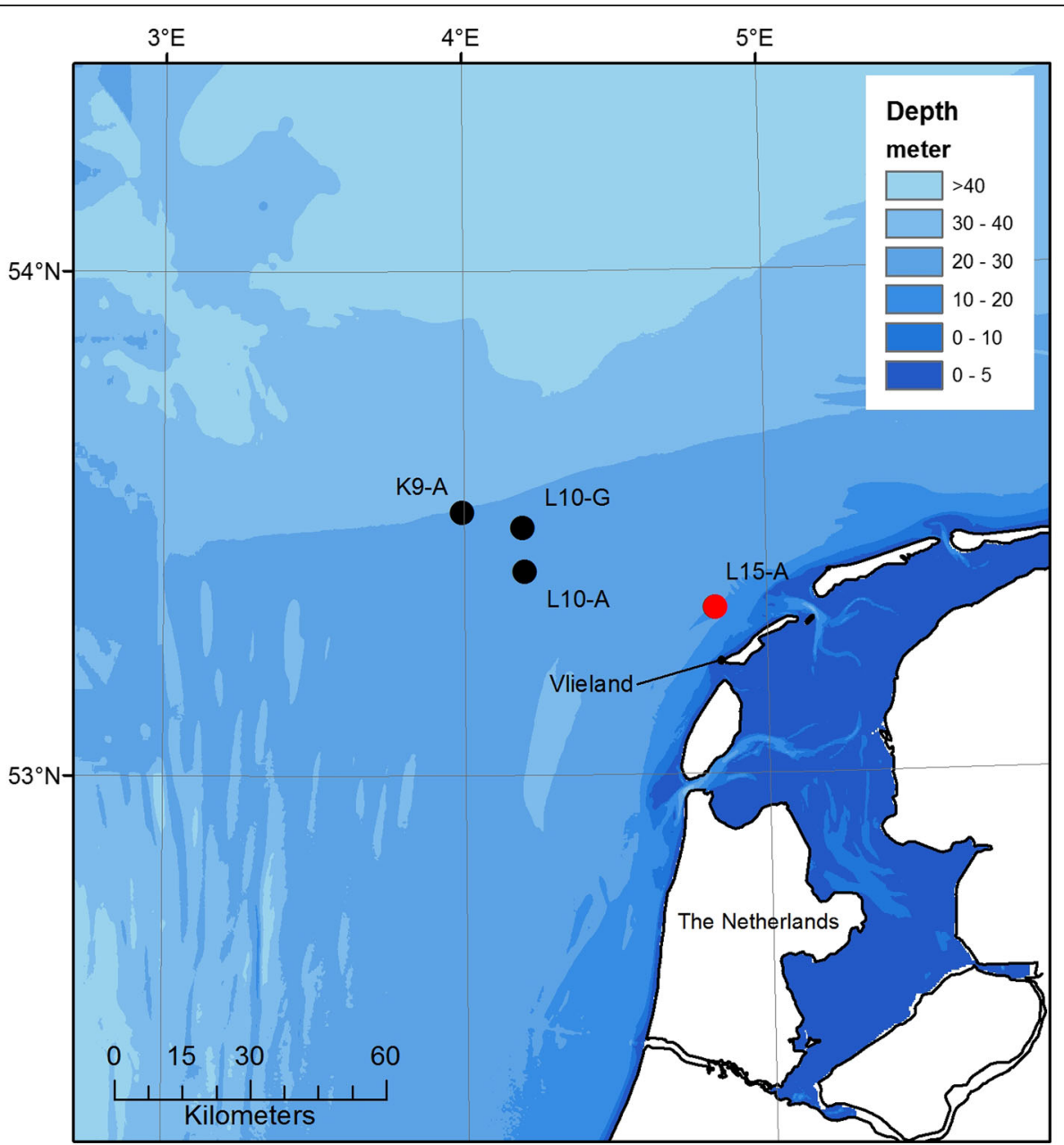

Fig. 1 Locations of the samples platforms for the RECON project (black \& red bullets). The two specimens of H. aspera were found on platform L15-A (53.3295 N $4.8301^{\circ}$ E; red bullet)

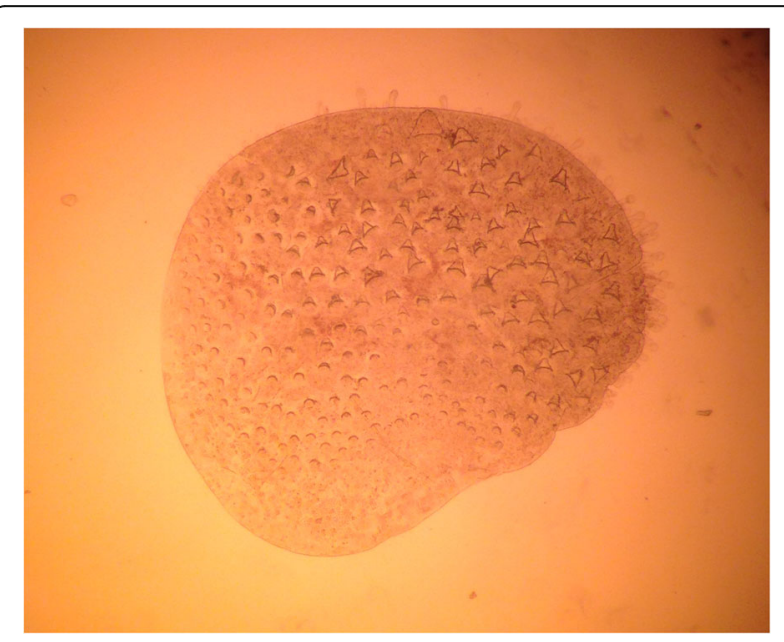

Fig. 2 Elytron of Harmothoe aspera. Characteristic for of H. aspera are the large pyramid shaped macrotubercles on the posterior margin of the elytra. The Photo was taken by Martijn Spierings during the discovery of the first $H$. aspera specimen
(4 spp). H. aspera was observed close to the seabed, but was not present in samples taken from the rocks at the bottom of the platform.

\section{Discussion}

The presence of $H$. aspera of the coast of Vlieland represents its first ever record in the Dutch EEZ. Since its first discovery in 1879 information on $H$. aspera has been scarce with only a few records since the 1970's.

The original description from Hansen (1879) contains habitat information on bottom materials, depth and temperature. Besides this account no further descriptions can be found within other records that give information about the habitat of $H$. aspera. There are also no recorded descriptions about its lifecycle or reproduction. There are only species records containing a year and sometimes a depth is listed. Harmothoe aspera is found in different seas all over the world. In 1876-1878 it has been recorded during the Norwegian North-Atlantic Expedition (Hansen 1879), in 1973 it was recorded in the 
Strait of Georgia on a 52 year old telephone cable (Levings and McDaniel 1974), in the 1990's it was found for the first time in the Western Mediterranean (Barnich and Fiege 2000) and around 2006-2008 it was recorded in the Barents Sea (Anisimova et al. 2010). It appears that $H$. aspera is mostly observed at a depth range between 200 and $300 \mathrm{~m}$, although it has also been observed at shallower depths of $48 \mathrm{~m}$ in the waters of Sweden. It must be noted that our depth record $(15-20 \mathrm{~m})$ is the shallowest depth record for $H$. aspera to date.

$H$. aspera remains a species of which very little is known. The observation of $H$. aspera on artificial hard substrate in the North Sea emphasizes the importance of investigations of benthic communities on these structures. This finding increases the diversity of Polynoidae found on artificial hard substrates.

\section{Acknowledgments}

The work reported in this publication was funded through the Wageningen UR TripleP@Sea Innovation program (J.C., KB-14-007) and by the Dutch Department of Economic Affairs (J.C., KB-24-16), the Nederlandse Aardolie Maatschappij BV, Wintershall Holding GmbH and Energiebeheer Nederland B.V. and the INSITE North Sea fund via the RECON project.

ENGIE Exploration \& Production Nederland B.V. allowed and facilitated us to sample their installations and we are especially grateful to Ed Schmidt, Nathalie Kaarls, Ulf Sjöqvist, Maico Vrijenhoeff, Ben Waardenburg and Kees van Braak for their help arranging this cooperation.

Further help was provided by Ruth Barnich who confirmed the identification.

\section{Availability of data and materials}

The data that supports the findings of this study is available from Wageningen Marine Research, but restrictions apply to the availability of these data, which were used under license for the current study, and so are not publicly available. Data is however available from the authors upon reasonable request and with permission of Wageningen Marine Research This data may consist of information on samples, species lists and availability of the specimens.

\section{Authors' contributions}

MS and IMD carried out the identification of Polynoidae for the 15-A platform and cooperated in writing this article. JWPC did the sampling, designed the study RECON project (Reef effects of structures in the North Sea) and cooperated in writing this article. BvdW and JC assisted with identifying the samples and cooperated in writing this article. All authors read and approved the final manuscript.

\section{Ethics approval and consent to participate}

No ethical approval or consent to participate was required.

\section{Consent for publication}

Authors gave consent to publish this MS.

\section{Competing interests}

The authors declare that they have no competing interests.

\section{Publisher's Note}

Springer Nature remains neutral with regard to jurisdictional claims in published maps and institutional affiliations.

\section{Author details}

'Wageningen Marine Research, P.O. Box 57, 1780 AB Den Helder, The Netherlands. ${ }^{2}$ Wageningen University, Chair group Aquatic Ecology and Water Quality Management, Droevendaalsesteeg 3a, 6708 PD Wageningen,
The Netherlands. ${ }^{3}$ Rijkswaterstaat, Ministry of Infrastructure and the Environment, Zuiderwagenplein 2, 8224 AD Lelystad, The Netherlands.

Received: 3 January 2017 Accepted: 3 November 2017

Published online: 15 November 2017

\section{References}

Anisimova N.A., Jørgensen L.L., Lyubin P.A. and Manushin I.E. (2010) Mapping and monitoring of benthos in the Barents Sea and Svalbard waters: Results from the joint Russian - Norwegian benthic programme 2006-2008. IMR-PINRO Joint Report Series 1-2010. ISSN 1502-8828. 114.

Barnich R. Identification of scale worms in British and Irish waters. Senckenberg Forschungsinstitut und Naturmuseum Frankfurt; 2011. p. 1-52.

Barnich R, Fiege D. Revision of the Mediterranean species of Harmothoe Kinberg, 1856 and Lagisca Malmgren, 1865 (Polychaeta: Polynoidae: Polynoinae) with descriptions of a new genus and a new species. J Nat Hist. 2000;34:1889-938. doi: 10.1080/00222930050144783.

Barnich R, Fiege D. Revision of the genus Harmothoe Kinberg, 1856 (Polychaeta: Polynoidae) in the Northeast Atlantic: Zootaxa. 2009;(2104):1-76.

Coolen JWP, Bos OG, Glorius S, Lengkeek W, Cuperus J, Van der Weide BE, Agüera A. Reefs, sand and reef-like sand: a comparison of the benthic biodiversity of habitats in the Dutch Borkum reef grounds. J Sea Res. 2015;103:84-92.

Ditlevsen H. Annelids. The Danish Ingolf Expedition, 4 (Part 4); 1917. p. 1-71.

Fauchald K, Jumars P. The diet of worms: a studie of Polychaete feeding gilds. Oceanogr Mar Biol Annu Rev. 1979;17:193-284.

Fiege D, Barnich R. Polynoidae (Annelida: Polychaeta) associated with cold-water coral reefs of the northeast Atlantic and the Mediterranean Sea. Zoosymposia. 2009;2(1):149-64.

Hansen GA. Annelider fra den norske Nordhavsexpedition i 1876. Nyt Magazin for Naturvidenskaberne. 1879;24:1-17. [In Norwegian]

Hassel A. (2014) MAREANO - base-line mapping of epifauna obtained with Beamtrawl. Institute of Marine Research, Norway. Retrieved March 232017 , from http://gbif.imr.no/ipt/resource.do?r=imr_mareano_beamtrawlhttps:// www.uptodate.com/contents/screening-for-depression-in-adults

Holte B. MAREANO - base-line mapping of fauna obtained with grab. Norway: Institute of Marine Research; 2014. Retrieved March 23 2017, from http:// www.iobis.org/explore/\#/dataset/3430

Levings CD, McDaniel NG. A unique collection of baseline biological data : benthic invertebrates from an underwater cable across the strait of Georgia; 1974. p. 19.

Martin D, Britayev T. Symbiotic Polychaetes: review of known species. Oceanogr Mar Biol Ann Rev. 1998;36:217-340. doi: 10.1016/j.catena.2010.08.006.

Nishimura S. The zoogeographical aspects of the Japan Sea part III. Publications of the Seto marine biological. Laboratory. 1966;13(5):365-84.

Nygren A, Pleijel F. Ringmaskar: Havsborstmaskar, Annelida: Polychaeta. Swedish University of Agricultural Sciences, Uppsala; 2015. p. 360. [In Swedish]

Ramos, M. (2010) . IBERFAUNA. The Iberian Fauna Databank. Retrieved April 22 2017, from http://iberfauna.mncn.csic.es/. [In Spanish].

Schmelk L. Chemistry. In: The Norwegian North-Atlantic expedition 1876-1878. Christiania: Grøndahl \& Søn; 1882. p. 1-71.

Swedish Agency for Marine and Water Management. SHARK - marine soft bottom macrozoobenthos monitoring in Sweden since 1971. Swedish Meteorological and Hydrological Institute (SMHI). 2015;

Submit your next manuscript to BioMed Central and we will help you at every step:

- We accept pre-submission inquiries

- Our selector tool helps you to find the most relevant journal

- We provide round the clock customer support

- Convenient online submission

- Thorough peer review

- Inclusion in PubMed and all major indexing services

- Maximum visibility for your research

Submit your manuscript at www.biomedcentral.com/submit
) BioMed Central 